\title{
Reclassification of Giant Viruses Composing a Fourth Domain of Life in the New Order Megavirales
}

\author{
Philippe Colson ${ }^{\mathrm{a}, \mathrm{b}} \quad$ Xavier de Lamballerie $^{\mathrm{b}, \mathrm{c}} \quad$ Ghislain Fournous $^{\mathrm{a}}$ Didier Raoult $^{\mathrm{a}, \mathrm{b}}$

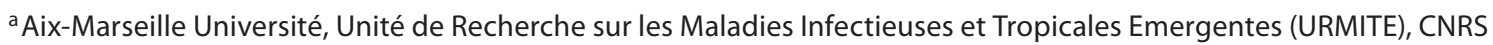
UMR 6236 - IRD 198 - INSERM 1095, Méditerranée Infection, Facultés de Médecine et de Pharmacie, bôle des Maladies Infectieuses et Tropicales Clinique et Biologique, Fédération de Bactériologie-Hygiène-Virologie, Centre Hospitalo-Universitaire Timone, Assistance publique des hôpitaux de Marseille, et ' ${ }^{C}$ nité des Virus Emergents, UMR190 Emergence des pathologies virales, Aix-Marseille Université, Institut de Recherche pour le Développement, EHSP French School of Public Health, Faculté de Médecine, Marseille, France
\end{abstract}

\section{Key Words}

Megavirales · Giant virus · Acanthamoeba polyphaga

Mimivirus - Mimiviridae - Nucleocytoplasmic large DNA

viruses $\cdot$ Amoeba $\cdot$ Acanthamoeba spp. Phagocytic

protist $\cdot$ Classification $\cdot$ Domains of life

\begin{abstract}
Interest in giant viruses has risen sharply since 2003 , following the discovery of the Mimivirus and four other protist-infecting giant viruses that are linked to the nucleocytoplasmic large DNA viruses (NCLDVs). Despite considerable heterogeneity in hosts and genome sizes, the NCLDVs have been shown to be monophyletic based on analyses of their sequences and gene repertoires and recent studies have proposed that these viruses share a common ancient ancestor and compose a fourth domain of life. In addition, several characteristics of these giant viruses contradict or do not match the criteria used for the canonical definition of viruses, and the NCLDV denomination is not completely appropriate. We propose here to define a new viral order named Megavirales.

Copyright $\odot 2012$ S. Karger AG, Basel
\end{abstract}

\section{(c) 2012 S. Karger AG, Basel 0300-5526/12/0555-0321\$38.00/0 \\ Karger \\ Open access}

This is an Open Access article licensed under the terms of the Creative Commons Attribution- NonCommercial-NoDerivs 3.0 License (www.karger.com/OA-license), applicable to the online version of the article only. Distribution for non-commercial purposes only.

\section{Introduction}

The existence of viruses with singularly large particle and genome sizes has been appreciated since the discovery of jumbo bacteriophages in the 1970s and the phycodnaviruses in the early 1980s [1,2]. The interest in giant viruses increased dramatically in 2003 with the discovery of Acanthamoeba polyphaga Mimivirus, whose genome was the largest ever described among viruses $(1,181 \mathrm{~kb})$. It encodes more than 900 proteins, including some never identified previously in viruses $[3,4]$. Overall, the Mimivirus discovery has led to considerable breakthroughs in our understanding of the definition, origin, and evolution of viruses [4-7]. Consequently, the number of publications and citations related to giant viruses has increased by more than $1 \log$ (online suppl. fig. S1; for all online suppl. material, see www.karger.com/doi/10.1159/000336562). Since 2008, several new giant viruses including close relatives to Mimivirus (Mamavirus, Terra2, Moumou, Courdo 11, Megavirus chilensis) and others more distantly related (Cafeteria roenbergensis virus (CroV), Marseillevirus, and Lausannevirus) have been recovered from different phagocytic protists and water samples by four teams (table 1; online suppl. table S1; fig. 1a) [5, 8-14].

Prof. Didier Raoult, MD, PhD

Unité des Rickettsies, URMITE UMR CNRS 6236 IRD 198

Faculté de Médecine, Aix-Marseille Université

27 Boulevard Jean Moulin, FR-13385 Marseille Cedex 05 (France)

Tel. +33 491324 375, E-Mail didier.raoult@gmail.com 


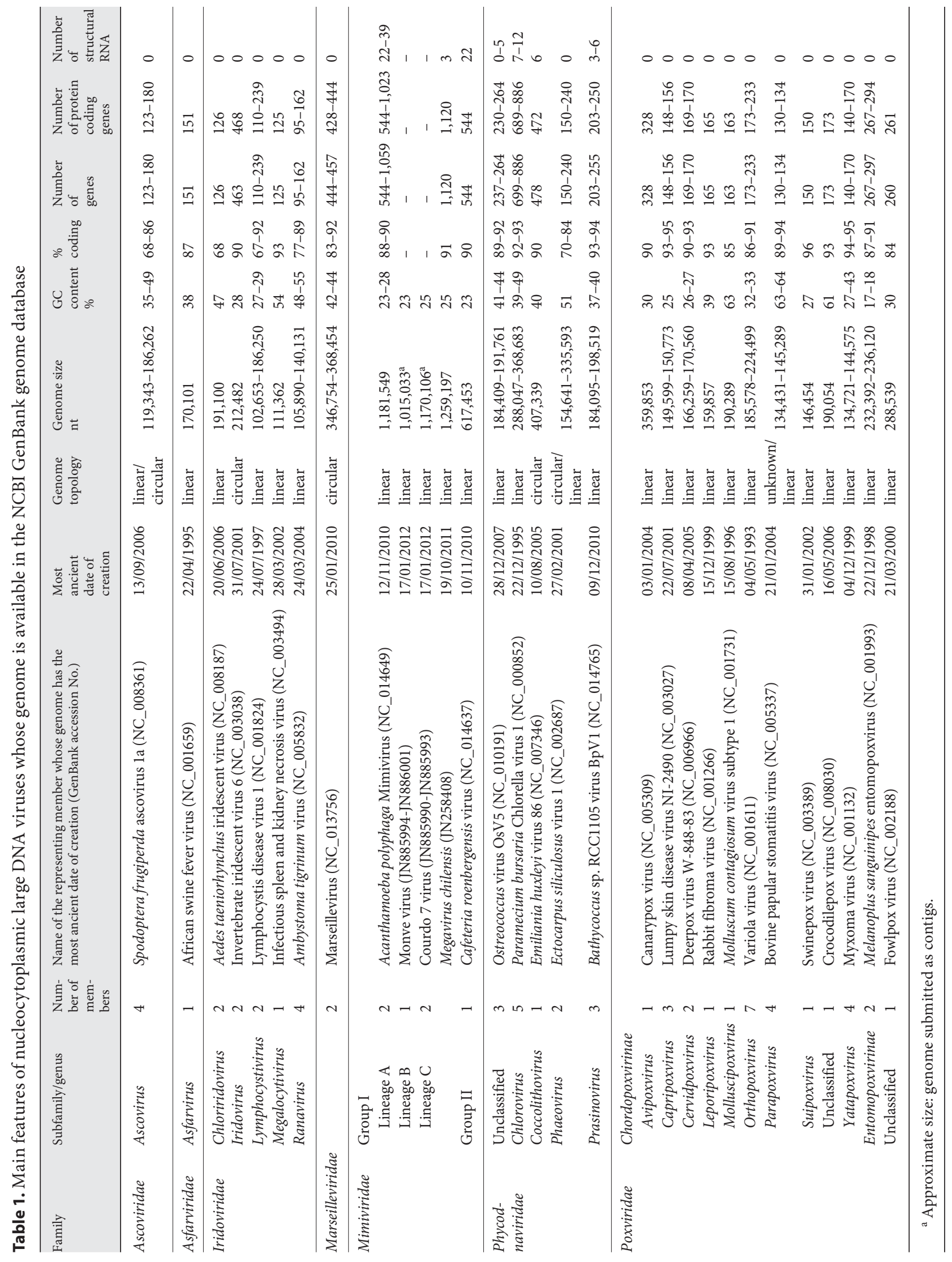




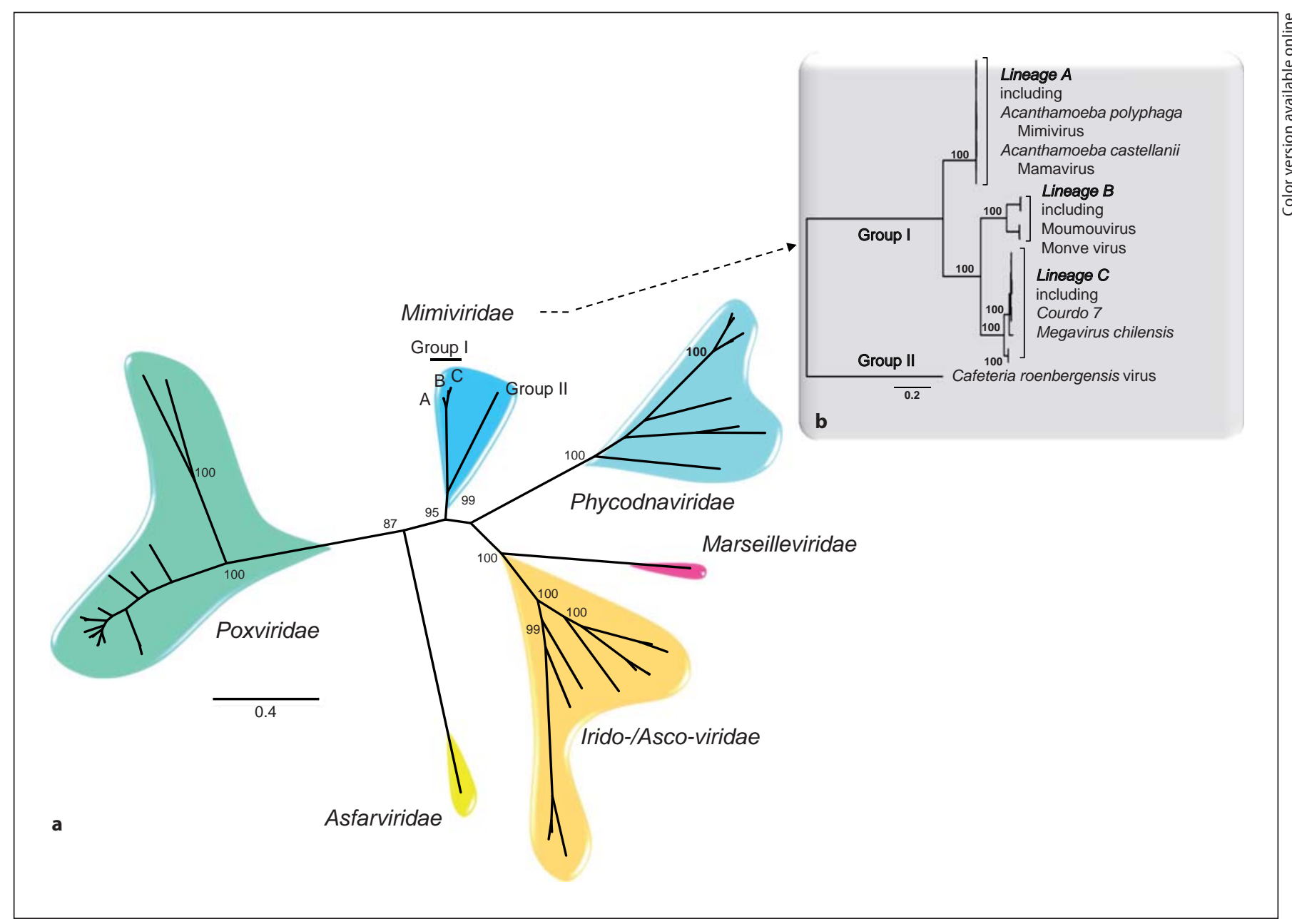

Fig. 1. Phylogeny reconstruction from a cured concatenated alignment of universal NCVOGs [including primase-helicase (NCVOG0023), DNA polymerase (NCVOG0038), packaging ATPase (NCVOG0249), and A2Llike transcription factor (NCVOG0262)] for the giant viruses currently classified as NCLDVs (a) [modified from 14] and the Mimiviridae (b). Probabilities are mentioned near branches as a percentage and are used as confidence values of tree branches. Only probabilities at major nodes are shown. Scale bar represents the number of estimated changes per position for a unit of branch length.

All of the previously mentioned protist-associated giant viruses have been linked to nucleocytoplasmic large DNA viruses (NCLDVs) (tables 1-4) [15-18]. However, this grouping is not completely appropriate and several unique features of the NCLDVs do not match the criteria for the canonical definition of viruses $[6,32,33]$. In addition, these giant viruses were suggested to share a common ancestral origin and compose a new domain of life, aside Bacteria, Archaea, and Eukarya [17, 18, 34]. Therefore, we propose here to define a new viral order named Megavirales.

Megavirales, a New Order of Giant Viruses

\section{Rationale and Argument Supporting the Definition of a New Viral Order}

The Current Definition and Classification of Giant

Viruses Are Inappropriate

The canonical definition of viruses was described by Lwoff [33] during the pregenomic era in 1957 and was historically based on negative criteria (online suppl. table S2). Later, genomics failed to identify any common gene in the virosphere that could be equivalent to universal proteins or ribosomal RNA for Eukarya, Archaea, and Bacteria [6,35-37]. Thus, viruses remained separate from 
Table 2. Brief description of the main features of NCLDVs

\begin{tabular}{ll}
\hline Family name & Main features \\
\hline Poxviridae & $\begin{array}{l}\text { Poxviridae include member species infecting insects (Entomopoxvirinae) and vertebrates (Chordopoxvirinae) [19]. Several gen- } \\
\text { era of poxviruses cause human illness, including Orthopoxvirus and Parapoxvirus, and a majority of the infections involving } \\
\text { these viruses are zoonoses. Poxviruses are complex viruses whose genome contains inverted terminal repeats between }<0.1 \text { and } \\
12.4 \mathrm{~kb} \text { in size, and strands of DNA at the genome termini that are covalently linked to produce hairpins [19, 20]. }\end{array}$ \\
\hline
\end{tabular}

Iridoviridae Iridoviruses infect invertebrates and poikilothermic vertebrates, including insects, fish, amphibians, and reptiles [21]. Their viral genomes are both circularly permuted and terminally redundant, which is a unique feature among eukaryote-infecting virus genomes [21, 22]. They are classified into five genera: Iridovirus, Chloriridovirus, Ranavirus, Lymphocystivirus, and Megalocytivirus. Their genomes contain frequent complex repeat sequences.

Ascoviridae The ascoviruses were discovered in the 1970s and classified as a single genus, Ascovirus, within the family Ascoviridae [23, 24]. They infect the lepidoptera (moths and butterflies). These viruses harbor large membrane-bound vesicles whose formation is unique in the viral world and which are responsible for their name. At least 12 different proteins, ranging in size from 11 to $200 \mathrm{kDa}$, are present in virions [24]. The ascovirus genome has a complex organization [23,24]. Ascoviridae represent a unique family of insect viruses and are most closely related to the invertebrate iridoviruses $[16,24]$.

Asfarviridae The Asfarviridae family is represented exclusively by the African swine fever virus, the agent of a fatal hemorrhagic disease in domestic swine $[25,26]$.

Phycodnaviridae The Phycodnaviridae are lytic and lysogenic viruses and are represented by three major viruses: Paramecium bursaria Chlorella virus 1 (PBCV-1), Emiliana huxleyi virus (EhV), and Ectocarpus siliculosus virus (EsV), which belong to the genera Chlorovirus, Coccolithovirus, and Phaeovirus, respectively [27, 28].

The PBCV-1 genome has covalently closed hairpin termini flanked by approximately 2.2 -kb inverted repeats $[28,29]$.

The EsV-1 genome has a relatively low gene density and inverted repeats at each end that allow circularization [27-29]. It is integrated into the host genome and passes to the daughter cells during cell division.

The EhV-86 genome may have linear and circular phases. Ectocarpus siliculosus virus 1 infects the gametes or spores of filamentous marine brown macroalgae. In contrast to the Chlorella viruses and EsV-1 that depend on host transcription machinery (PBCV-1 lacks a recognizable RNA polymerase gene), EhV has six RNA polymerase-encoding genes [30].

It is noteworthy that the Phycodnaviridae hosts are widely distributed. Indeed, Chlorella are green algae that are among the most widely distributed and most frequently encountered algae $[28,29]$. Emiliania huxleyi, the host of EhV, is also a ubiquitous unicellular marine phytoplankton that is thought to be important in ocean carbon and sulfur cycles [31]. Ectocarpus siliculosus is a member of benthic communities in the near-shore coastal environments of all the world's oceans [28].

Mimiviridae Acanthamoeba polyphaga Mimivirus has been described in 2003 and was the largest virus [3, 4]. It has been assigned to a new viral family: the Mimiviridae [4]. Acanthamoeba castellanii Mamavirus, another strain of Mimivirus, was described in 2008 [5]. In 2010, several new giant viruses recovered by culture on amoebae have been described and phylogeny reconstructions based on highly conserved genes delineate three lineages (referred to as A, B and C) that compose a first group among the Mimiviridae (fig. 1b). One of these lineages (A) is composed of Mimivirus and closely related viruses [9]. A new Mimiviridae member, Megavirus chilensis, was recently described [10]. It falls undoubtedly within lineage C, being closely related to a previously recovered giant virus, Courdo 11 virus [9]. In 2010, Cafeteria roenbergensis virus was described and linked to the Mimiviridae family, away from the group consisting of three lineages A, B and C $[11,14]$. This virus infects a widespread marine heterotrophic flagellate that belongs to the Chromalveolata phylum, and not Acanthamoeba sp. as Mimivirus and Mamavirus.

Marseilleviridae $^{a} \quad$ The Marseilleviridae family is a putative new viral family among the NCLDVs. Marseillevirus was discovered in 2007 in water collected from a cooling tower in Paris, France [12]. In 2011, a close relative to Marseillevirus, named Lausannevirus, was described [13]. The Lausannevirus genome shares $89 \%$ of genes with the Marseillevirus genome.

a Putative new viral family.

these biological entities. Recently, a new classification was proposed, which defines them as capsid-encoding organisms as opposed to ribosome-encoding organisms that compose the three canonical domains of life and are used to complete the viral life cycle (fig. 2). Besides, major monophyletic classes of viruses were tentatively defined $[15,37]$. Most giant viruses were linked to one of these classes, NCLDV, which includes Poxviridae, Asfarviri- dae, Iridoviridae, Ascoviridae, Phycodnaviridae, Mimiviridae, and Marseilleviridae (Marseillevirus and Lausannevirus) (tables 1-3; fig. 1a; online suppl. table S1) [13, 17]. Regarding Mimiviridae, new giant viruses infecting amoebae have been described by La Scola et al. [9] in 2010 and phylogeny reconstructions based on highly conserved genes enable delineating three lineages, referred to as $\mathrm{A}, \mathrm{B}$, and $\mathrm{C}$. One of these lineages $(\mathrm{A})$ is composed of 
Table 3. A brief history of key steps in the definition of the NCLDV superfamily and the Megavirales order

\begin{tabular}{|c|c|}
\hline Reference & Major findings \\
\hline $\begin{array}{l}\text { Iyer et al., } \\
2001 \text { [15] }\end{array}$ & $\begin{array}{l}\text { The NCLDV group was conceived in } 2001 \text { by Iyer et al. [15] on the basis of comparative analyses of viral genomes that aimed to } \\
\text { delineate a complete set of conserved genes. The NCLDVs originally consisted of four families of viruses, Poxviridae, Asfarviridae, } \\
\text { Iridoviridae, and Phycodnaviridae, which harbor a large double-stranded DNA genome greater than 200,000 bp in size and sharing } \\
9 \text { genes (and } 22 \text { additional genes found in at least three of these four viral families). }\end{array}$ \\
\hline $\begin{array}{l}\text { Raoult et al., } \\
2004 \text { [4] }\end{array}$ & $\begin{array}{l}\text { The genome of Mimivirus was described in } 2004 \text { and was the largest for a virus, being larger than that of several bacterial and ar- } \\
\text { chaeal parasites [ } 3,4] \text {. This genome is a double-stranded linear DNA molecule of } 1,181,404 \text { bp. Raoult et al. [ } 4 \text { ] have identified } 1,262 \\
\text { ORFs, of which } 911 \text { were predicted to be protein-coding genes. A total of } 298 \text { ORFs ( } 24 \% \text { of the predicted genes) were able to be } \\
\text { associated with functional attributes. Among the predicted ORFs, } 194 \text { matched significantly with } 108 \text { clusters of orthologous } \\
\text { groups. Mimivirus led to the definition of a new family among NCLDVs: Mimiviridae. }\end{array}$ \\
\hline $\begin{array}{l}\text { Iyer et al., } \\
2006 \text { [16] }\end{array}$ & $\begin{array}{l}\text { In a work examining the Mimivirus genome and several other genomes recently available for three of the previously defined } \\
\text { NCLDV families, Iyer et al. [16] tentatively defined the gene complement of the ancestral NCLDV and found that it harbored at } \\
\text { least } 41 \text { core genes. They also identified a core gene set of } 11 \text { conserved genes in all the NCLDVs. Significant matches with sequence } \\
\text { databases were obtained and conserved domains were identified for } 188 \text { ORFs. }\end{array}$ \\
\hline $\begin{array}{l}\text { Boyer et al., } \\
2009 \text { [12] }\end{array}$ & $\begin{array}{l}\text { The Marseillevirus was isolated using amoebal culture of water collected in a cooling tower [12]. Its genome is a circular, double- } \\
\text { stranded DNA molecule of 368,453 bp. A total of } 457 \text { ORFs have been predicted to encode proteins. Phylogenetic analyses have } \\
\text { shown that Marseillevirus belongs to a new viral family of NCLDVs. It has been highlighted that its genome includes genes of } \\
\text { likely bacterial, archaeal, eukaryotic, and viral origins. This mosaic gene content has supported the model of amoebae as hot spots } \\
\text { for gene gain and exchange between entities with a sympatric intra-amoebal lifestyle. The genome of Lausannevirus, a close relative } \\
\text { of the Marseillevirus, was described in } 2011 \text { [13]. It was recovered using amoebal co-culture from a water sample collected in the } \\
\text { Seine river that runs through Paris, France. }\end{array}$ \\
\hline
\end{tabular}

Yutin et al., 2009 [17]

In 2009, Yutin et al. [17] updated the core NCLDV gene set on the basis of constructing clusters of orthologous groups of proteins with an extended number of NCLDV genomes, including those of Mamavirus and Marseillevirus. They identified 1,445 NCLDV orthologous groups, so-called NCVOGs, including 177 represented in more than one NCLDV family and five including proteins from all 45 analyzed viruses. Additionally, they used a maximum-likelihood reconstruction of the evolution of NCLDVs to define a set of 47 conserved genes that were probably present in the genome of the NCLDV common ancestor. Yutin et al. proposed that NCVOGs might provide a helpful platform for genome analysis and functional annotation of newly characterized NCLDVs.

Koonin Koonin and Yutin [18] addressed the origins and evolution of NCLDVs. The NCLDVs infect diverse animals and protists and the and Yutin, NCLDV core genes appear to have various probable origins including eukaryotes, bacteria, and bacteriophages (fig. 3). Their results 2010 [18] suggest that the NCLDVs originated at an early stage in the evolution of eukaryotes.

La Scola et al., 19 new giant viruses have been recovered by improved amoebal culture protocols from 105 environmental samples, mostly water 2010 [9] [9]. For those linked to the Mimiviridae, phylogeny reconstruction of highly conserved proteins revealed three main lineages named A (that includes Mimivirus), B (whose leading member is Moumouvirus), and C composed of several members including Courdo 11 and Terra1 (table 1; fig. 1b). In 2011, Megavirus chilensis, another Mimiviridae that falls within group C, was described [10]. It is very closely related to Courdo 11 and has the largest genome amongst those released so far (table 1; fig. 1b).

Boyer et al., In 2010, phylogenetic and phyletic analyses based on the presence/absence patterns of informational genes (the genes involved in 2010 [34] DNA biosynthesis and processing, including nucleotide biosynthesis, DNA replication and repair, recombination, and transcription) shared by Eukarya, Bacteria, Archaea, and the NCLDVs, allowed the delineation of a fourth domain of life (consisting of the NCLDVs) that supports the monophyly and common origin of these giant viruses [34].

Fischer et al., The genome of the Cafeteria roenbergensis virus (CroV) was described in 2010 [11]. This virus infects a widespread marine het2010 [11] erotrophic flagellate that is phylogenetically distant from the amoebal host of the Mimivirus and Marseillevirus (Acanthamoeba sp.). The CroV genome has an estimated size of $730 \mathrm{~kb}$ and contains 544 putative ORFs. Phylogenetic reconstructions indicated that $\mathrm{CroV}$ is related to the Mimiviridae family, apart from the group composed by three lineages (fig. 1b). A new virophage that infects the Cafeteria roenbergensis virus, Mavirus, was subsequently described [35]; it was hypothesized that Maverick/Polinton transposons may have originated from ancient relatives of the Mavirus. 
Fig. 2. Schematic illustrating the relationships between ribosome-encoding organisms and capsid-encoding organisms, including the Megavirales members.

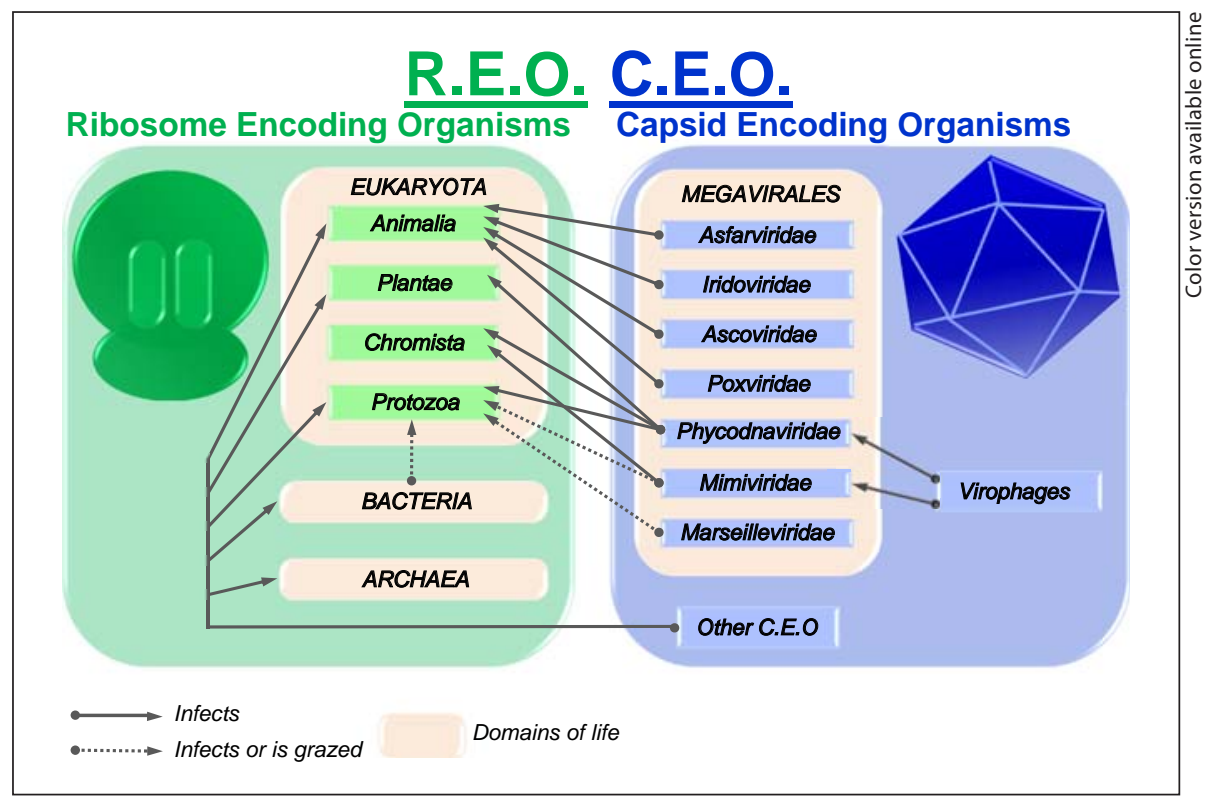

Table 4. Range of genome sizes, \% GC content, coding proportions of genomes, and numbers of genes for the seven nucleocytoplasmic large DNA virus family members whose genome sequences are available in the NCBI GenBank genome database

\begin{tabular}{|c|c|c|c|c|c|c|c|c|}
\hline \multirow[t]{2}{*}{ Family } & \multicolumn{2}{|c|}{ Genome size, nt } & \multicolumn{2}{|c|}{ GC content, $\%$} & \multicolumn{2}{|c|}{$\%$ coding } & \multicolumn{2}{|c|}{ Number of genes } \\
\hline & $\min$ & $\max$ & $\min$ & $\max$ & $\min$ & $\max$ & $\min$ & $\max$ \\
\hline Ascoviridae & 102,653 & 119,343 & 29 & 55 & 79 & 92 & 99 & 110 \\
\hline Asfarviridae & 170,101 & 170,101 & 38 & 38 & 87 & 87 & 151 & 151 \\
\hline Poxviridae & 134,431 & 359,853 & 17 & 64 & 80 & 96 & 130 & 328 \\
\hline Marseilleviridae & 346,754 & 368,454 & 42 & 44 & 83 & 92 & 444 & 457 \\
\hline Iridoviridae & 102,653 & 212,482 & 27 & 55 & 67 & 93 & 95 & 463 \\
\hline Phycodnaviridae & 154,641 & 407,339 & 37 & 51 & 70 & 94 & 150 & 886 \\
\hline Mimiviridae & 617,453 & $1,259,197$ & 23 & 28 & 88 & 91 & 544 & 1,120 \\
\hline
\end{tabular}

Mimivirus and closely related viruses (table 1; fig. 1b). The recently described Megavirus chilensis [10] is closely related to a giant virus previously recovered and classified within lineage $\mathrm{C}$ (table 1; fig. 1b). CroV has been also classified among the Mimiviridae, apart from the group composed by the lineages $\mathrm{A}, \mathrm{B}$, and $\mathrm{C}$ (table 1; fig. 1b) [11, 14].

Despite large heterogeneity in their hosts and genome sizes, the monophyly of the NCLDVs has been attested by phylogenetic and phyletic analyses, and the gene repertoires of these viruses distinguished them from bacteria, archaea, and eukaryotes $[15,18,37]$. The NCLDVs were originally defined as sharing nine genes found in all families, including three viral hallmark genes (table 3) [15]. Later, Yutin et al. [17] identified a set of 1,445 NCLDV clusters of orthologous groups of proteins, referred to as NCVOGs, that included 177 represented in two or more NCLDV families and 5 present in all viruses. Other viruses, including Myoviridae, Nimaviridae, Herpesviridae, and Polydnaviridae, exhibit large genome and particle sizes, but their gene content precludes their incorporation within the NCLDVs $[15,37]$. Some viral hallmark genes are shared between the NCLDVs and other large DNA viruses, as exemplified by the B-family DNA polymerases that are shared with herpesviruses and baculoviruses, but there are considerable numbers of other genes shared by the NCLDVs to the exclusion of all other large viruses [17, 37]. Moreover, the DNA replication and transcription of herpesviruses and baculoviruses occur exclusively in the 
Fig. 3. Functional annotation and probable origin of the reconstructed core gene set of the common ancestor of the NCLDVs (47 NCVOGs) [adapted from 18].

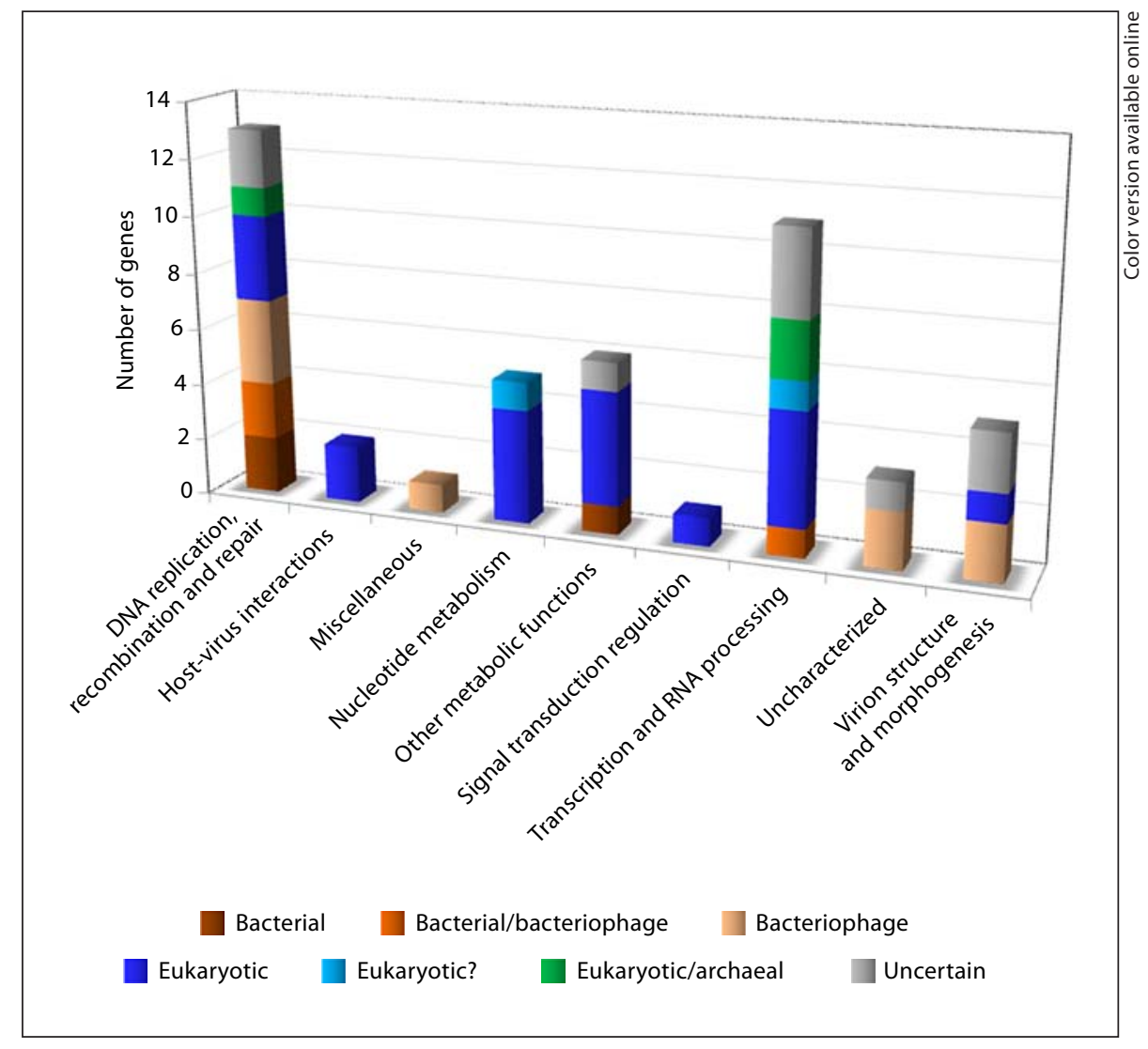

nucleus, in contrast to NCLDVs [15]. Regarding Myoviridae, they are tailed bacteriophages [28].

Based on current knowledge, giant viruses and other canonical viruses differ in many aspects, which is not consistent with the concept (conveyed by Lwoff's classification) that the viral world is a homogeneous class of entities (online suppl. table S2) $[6,16,32]$. As an example, the huge gap between the Mimivirus and the hepatitis $\mathrm{C}$ virus is striking. The specific NCLDV features that strongly challenge the canonical definition of viruses are listed below (online suppl. table S2).

The NCLDVs have a capsid diameter that ranges between 150 and $500 \mathrm{~nm}$, which contradicts the historical concept of viruses as small, ultrafilterable entities [32, 38-40]. In addition, the NCLDVs have large genomes that range in size between 103 and $1,259 \mathrm{~kb}$ and harbor 951,120 genes (table 4 ).

Viral messenger RNAs were detected in Mimivirus and Marseillevirus particles [4, 12]. These transcripts encode notably for capsid protein, DNA polymerase, or TFII-like transcription factor. The presence of RNA in the vaccinia virus particles has also been reported [41]. This contradicts a key point of Lwoff's viral classification, which stated that viruses only harbor one type of nucleic acid [32, 33].

The Mimiviridae and Marseilleviridae genomes encode proteins involved in translation, which represents a unique feature of these viruses $[4,12,32]$. Besides, the genomes of Mimiviridae and Phycodnaviridae exhibit tRNAs $[4,28]$.

The NCLDVs were suggested to have a common ancestral origin dating back to an early stage of Eukarya evolution (table 3) $[15,17,34,37]$. Thus, Yutin et al. [17] used maximum-likelihood reconstruction to delineate a set of 47 conserved genes that were probably present in the genome of the NCLDV common ancestor, which may have been a giant virus (fig. 3). Additionally, the NCLDVs infect a considerable diversity of hosts that belong to the three canonical domains of life [17, 28, 42]. Moreover, cross-mapping of the NCLDV and host eukaryotic trees generated a complex network in which members of the same NCLDV branch exhibited relationships with eukaryotic organisms of different supergroups [17]. For example, despite the relationship between them, irido-/ascoviruses infect animals, while Marseillevirus infects a 
protist. Yutin et al. [17] have proposed the hypothesis of a 'Big Bang-like' event concomitantly with eukaryogenesis for the origin of the NCLDVs [43].

Furthermore, it was proposed in 2010 that NCLDVs might define a fourth domain of life. This has been based on phylogenetic and phyletic studies of the repertoires of genes involved in information storage and processing and nucleotide transport and metabolism, and shared by $\mathrm{Eu}$ karya, Bacteria, Archaea, and the NCLDVs [34]. This work provided additional data supporting the monophyly and common origin of these giant viruses. In addition, it supports the hypotheses that the core genome of the NCLDVs may be as ancient as those of the three current canonical domains of life and that NCLDVs may have emerged as ancient roots from the rhizome of life $[34,44]$. It was claimed in a recent work that the methodology used by Boyer et al. [34] for phylogenetic reconstructions was not the most appropriate to avoid spurious tree topologies generated by compositional heterogeneity and homoplasy, and alternative informational gene phylogenies did not support a fourth domain of life for NCLDVs [45]. Nevertheless, these trees fail to show a monophyly of Eukarya as well. In addition, other recent findings based on extensive analysis of metagenomic data suggest the existence of domains other than Eukarya, Archaea, and Bacteria [46].

\section{Other Major Features of Giant Viruses Classified} Along with NCLDVs

The NCLDVs can be characterized by other peculiar features in addition to those that radically classify them as separate from other viruses.

Poxviridae, Iridoviridae, and Asfarviridae can build viral factories [47], also reported in the case of Mimivirus, Megavirus, Marseillevirus, and Lausannevirus [10, $12,13,48]$. These factories are associated with a massive production of virions.

The NCLDVs display a high level of genomic plasticity. Indeed, lineage-specific gene expansion and horizontal gene transfer have played a major role in the shaping of their genomes $[4,42,49-53]$. The proportion of duplicated genes in these viruses was found to range between 8 and $44 \%$, with the highest proportions observed in Mimivirus $[50,51]$. In addition, horizontal gene transfer has generated considerable genome plasticity and mosaicism, although the direction or source of the transfers and the fraction of gene content involved remain controversial [7, 51]. According to Filée [51], 0.8-11.9\% of the genes were exchanged with the viral hosts, with the highest proportion being observed in Poxviridae, and up to $9.6 \%$ of the gene content was exchanged with bacteria, with the high- est proportion being in Mimivirus. The potential mechanisms by which Poxviridae shape their genome through transfers of genes of host or viral origin have been particularly described [54-57]. In addition, the numbers of gene transfers with bacteria are the greatest for the Mimiviruses, Marseilleviruses, and phycodnaviruses that infect hosts feeding on bacteria [42]. The sympatric lifestyle within a phagocytic protist that grazes on bacteria, giant viruses, and virophages provides many opportunities indeed for these pathogens to gain and exchange genes. Thus, amoebae have been described as hot spots for gene transfer that may lead to the emergence of chimeric viruses and even the creation of new species $[12,58]$. Interestingly, a reduction in genome size by approximately $16 \%$ was recently observed for the Mimivirus when subcultured 150 times in a germ-free amoebal host [59].

In addition to the core gene set, NCLDV genomes contain open reading frames (ORFs) without detectable homologs, also known as ORFans [60]. Strikingly, 2.8$75.2 \%$ of ORFs in the NCLDV genomes lack homologs in the NCBI GenBank reference protein sequence database. Moreover, $0.3-10.4 \%$ of these ORFs have homologs in the GenBank environmental protein sequence database.

The NCLDVs themselves can be infected by viruses [61], as has been previously shown for eukaryotes, bacteria, and archaea. In 2008, La Scola et al. [5] identified Sputnik, a virus infecting Mamavirus, which led to the creation of the virophage concept. Since then three new virophages have been described in association with Mimiviridae and Phycodnaviridae [9, 35, 62]. Importantly, virophages may be involved in gene transfer $[5,35]$.

\section{Giant Viruses Classified with the NCLDVs Are}

Probably Common Inhabitants of Our Biosphere

According to our current knowledge, the NCLDVs remain a minority in the virosphere. Nevertheless, several findings indicate that they are common inhabitants of our biosphere. It is noteworthy that their presence has probably been largely underestimated up to this point because most metagenomic studies have adhered to the dogma of the small size of viruses by filtering samples prior to analysis (fig. 4) [63-65]. Notwithstanding, sequences similar to those from Mimivirus, African swine fever virus, and iridoviruses have already been identified in marine environmental samples or human serum and sewage [66-71]. Furthermore, giant viruses have been recovered from five different geographical areas worldwide and they have been isolated from approximately $20 \%$ of water samples in one study by optimizing amoebal culture protocols [9]. 


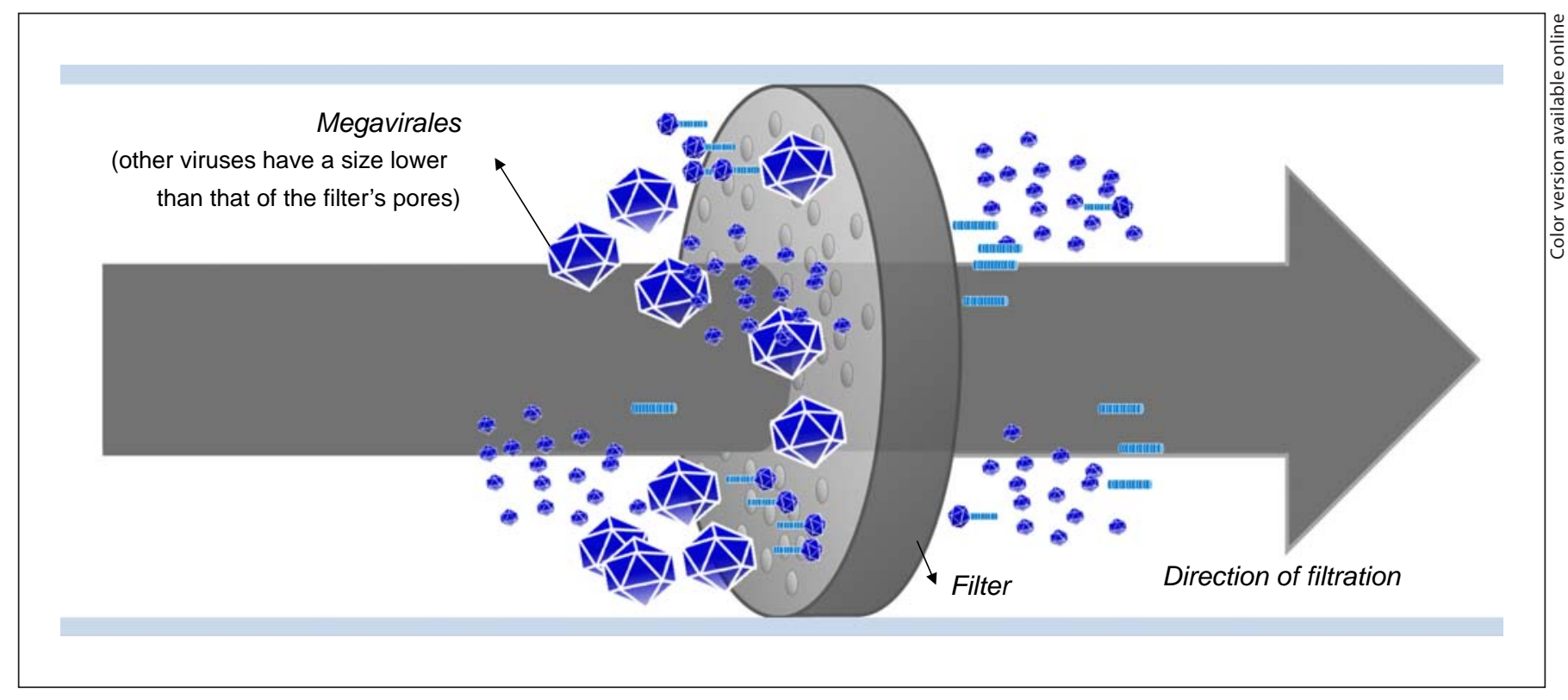

Fig. 4. Schematic illustrating how the giant viruses may have been excluded during the assessment of viromes by metagenomic studies that have filtered samples prior to analysis. Such procedures are inevitably preventing the detection of viruses larger than the pores of the filters used, i.e. $0.2-0.45 \mu \mathrm{m}$.

\section{NCLDV Is Not an Appropriate Denomination and}

Has No Recognized Taxonomic Meaning

Finally, the NCLDV denomination does not take into account that Mimivirus and Marseillevirus harbor both DNA and RNA. Moreover, the NCLDVs compose a superfamily, a grouping that has no formally recognized taxonomic meaning according to the International Committee on Taxonomy of Viruses (ICTV) (http://www. ictvonline.org/virusTaxonomy.asp?bhcp=1). In the current ICTV classification, none of the NCLDV families are assigned to a viral order. We propose that these viruses should be assigned to a newly defined order (a group of families sharing certain common characteristics according to the ICTV) named Megavirales, in reference to the uncommon size of both the members' particles and their genomes.

\section{Definition of the Megavirales}

Viral members of the new Megavirales order correspond to the giant viruses previously classified within the NCLDVs (table 1; online suppl. table S1). Megavirales can be defined by the criteria mentioned below, as illustrated in figure 5.

Megavirales, a New Order of Giant Viruses
All of the following single characteristics are required for membership in the order (the monothetical system [72]):

- Giant viral particle and genome, capsid diameter $>150 \mathrm{~nm}$ and genome size $>100 \mathrm{~kb}$ (or in that order of magnitude).

- Presence in the gene content of all nine class I NCLDV core genes, i.e. VV D5-type ATPase (superfamily III helicase), DNA polymerase (B family), VV A32 virion packaging ATPase, VV A18 helicase (superfamily II), capsid protein D13L, thiol oxidoreductase, VV D6R/ D11L-like helicase (superfamily II), S/T protein kinase, transcription factor VLTF2 [15] and all five NCVOGs found in all NCLDVs (i.e. NCLDV major capsid protein, D5-like helicase-primase, DNA polymerase elongation subunit family B, A32-like packaging ATPase and Poxvirus Late Transcription Factor VLTF3-like) [18]. These genes have various functions and origins.

- Common ancestral origin and membership in the proposed fourth domain of life.

- A jelly-roll capsid protein, which is a hallmark viral protein $[6,37]$. The capsid is icosahedral in all NCLDVs except in poxviruses, where it forms intermediate structures during virion morphogenesis, but is not a protein of the virion $[37,73]$.

Intervirology 2012;55:321-332 


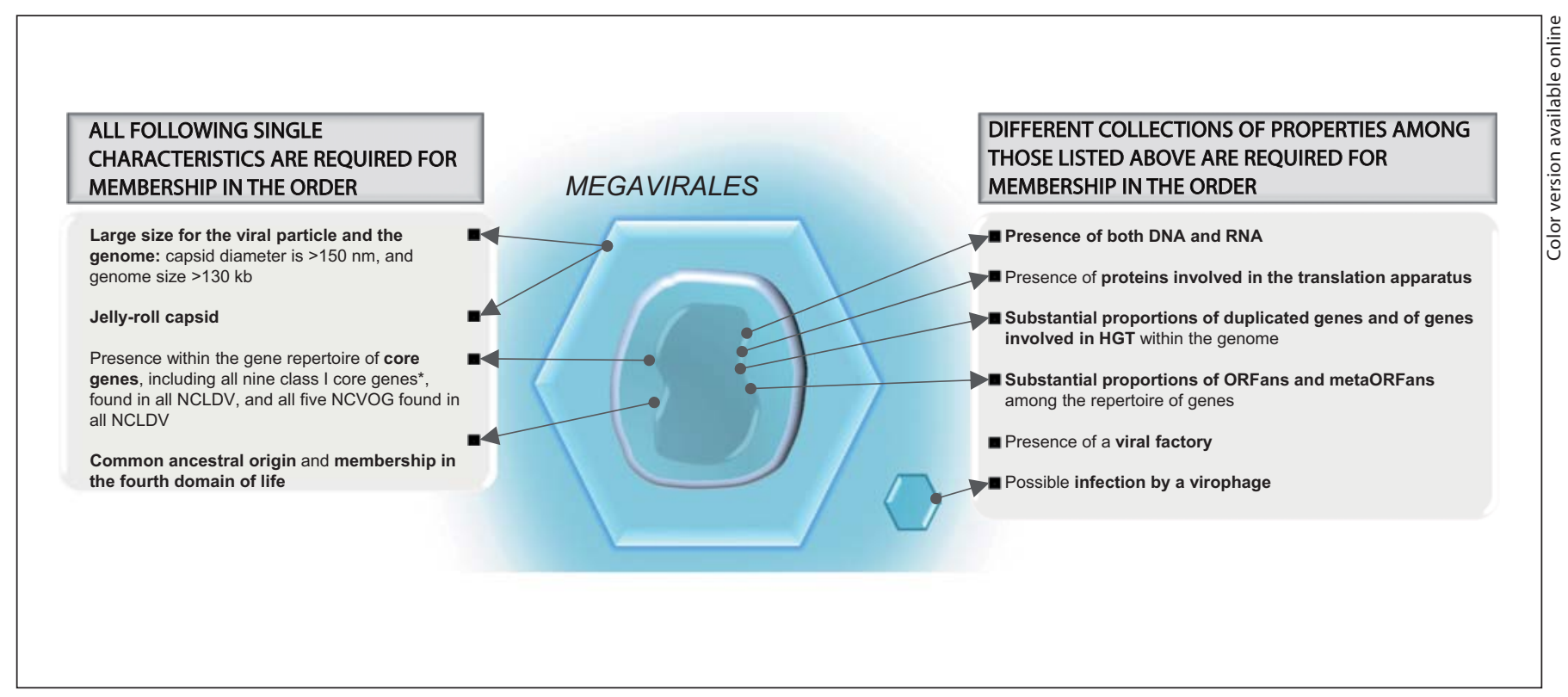

Fig. 5. Major features of Megavirales members and criteria required for membership in the Megavirales order.

Different combinations of properties among those listed above are required for membership in the order (the polythetical system): presence of both DNA and RNA; presence of proteins involved in the translation apparatus; substantial proportions of genes duplicated and involved in horizontal gene transfer within the genome; substantial proportions of ORFans and metaORFans among the gene repertoire; presence of viral factories; some or all steps of DNA replication and transcription occurring in the host cytoplasm, and possible infection by a virophage.

\section{Conclusion}

The tremendous recent increase in knowledge about giant viruses has generated divergence rather than reinforced the borders of the previously defined viral world. Megavirales gather viral entities that appear to be incompatible within the framework of the virosphere as it has been defined since the beginning of virology. Moreover, they lay the foundation for a new understanding in which viruses consolidate their status as early protagonists in evolution.

\section{References}

$\checkmark 1$ Donelli G, Dore E, Frontali C, Grandolfo ME: Structure and physico-chemical properties of bacteriophage G. III. A homogeneous DNA of molecular weight 5 times 10(8). J Mol Biol 1975;94:555-565.

-2 Van Etten JL, Meints RH, Kuczmarski D, Burbank DE, Lee K: Viruses of symbiotic Chlorella-like algae isolated from Paramecium bursaria and Hydra viridis. Proc Natl Acad Sci USA 1982;79:3867-3871.

3 La Scola B, Audic S, Robert C, Jungang L, de Lamballerie X, Drancourt M, Birtles R, Claverie JM, Raoult $\mathrm{D}$ : A giant virus in amoebae. Science 2003;299:2033.
4 Raoult D, Audic S, Robert C, Abergel C, Renesto P, Ogata H, La Scola B, Suzan M, Claverie JM: The 1.2-megabase genome sequence of Mimivirus. Science 2004;306: 1344-1350.

5 La Scola B, Desnues C, Pagnier I, Robert C, Barrassi L, Fournous G, Merchat M, SuzanMonti M, Forterre P, Koonin E, et al: The virophage as a unique parasite of the giant mimivirus. Nature 2008;455:100-104.

6 Raoult D, Forterre P: Redefining viruses: lessons from Mimivirus. Nat Rev Microbiol 2008;6:315-319.
7 Forterre P: Giant viruses: conflicts in revisiting the virus concept. Intervirology 2010;53: 362-378.

8 Colson P, Yutin N, Shabalina S, Robert C, Fournous G, La Scola B, Raoult D, Koonin EV: Viruses with over 1,000 genes: Acanthamoeba castellanii Mamavirus, a new mimivirus strain, and reannotation of Mimivirus genes. Genome Biol Evol 2011;3: 737-742.

$\checkmark 9$ La Scola B, Campocasso A, N'Dong R, Fournous G, Barrassi L, Flaudrops C, Raoult D: Tentative characterization of new environmental giant viruses by MALDI-TOF mass spectrometry. Intervirology 2010;53:344-353. 
10 Arslan D, Legendre M, Seltzer V, Abergel C, 25 Dixon LK, Abrams CC, Bowick G, Goatley Claverie JM: Distant Mimivirus relative with a larger genome highlights the fundamental features of Megaviridae. Proc Natl Acad Sci USA 2011;108:17486-17491.

- 11 Fischer MG, Allen MJ, Wilson WH, Suttle CA: Giant virus with a remarkable complement of genes infects marine zooplankton. Proc Natl Acad Sci USA 2010;107:1950819513.

12 Boyer M, Yutin N, Pagnier I, Barrassi L, Fournous G, Espinosa L, Robert C, Azza S, Sun S, Rossmann MG, et al: Giant Marseillevirus highlights the role of amoebae as a melting pot in emergence of chimeric microorganisms. Proc Natl Acad Sci USA 2009; 106:21848-21853.

-13 Thomas V, Bertelli C, Collyn F, Casson N, Telenti A, Goesmann A, Croxatto A, Greub G: Lausannevirus, a giant amoebal virus encoding histone doublets. Environ Microbiol 2011;13:1454-1466.

- 14 Colson P, Gimenez G, Boyer M, Fournous G, Raoult D: The giant Cafeteria roenbergensis virus that infects a widespread marine phagocytic protist is a new member of the fourth domain of Life. PLoS One 2011; 6:e18935.

$\checkmark 15$ Iyer LM, Aravind L, Koonin EV: Common origin of four diverse families of large eukaryotic DNA viruses. J Virol 2001;75: 11720-11734.

- 16 Iyer LM, Balaji S, Koonin EV, Aravind L: Evolutionary genomics of nucleo-cytoplasmic large DNA viruses. Virus Res 2006;117: 156-184.

17 Yutin N, Wolf YI, Raoult D, Koonin EV: Eukaryotic large nucleo-cytoplasmic DNA viruses: clusters of orthologous genes and reconstruction of viral genome evolution. Virol J 2009;6:223.

- 18 Koonin EV, Yutin N: Origin and evolution of eukaryotic large nucleo-cytoplasmic DNA viruses. Intervirology 2010;53:284-292.

19 Lefkowitz EJ, Wang C, Upton C: Poxviruses: past, present and future. Virus Res 2006;117: 105-118.

20 Baroudy BM, Venkatesan S, Moss B: Incompletely base-paired flip-flop terminal loops link the two DNA strands of the vaccinia virus genome into one uninterrupted polynucleotide chain. Cell 1982;28:315-324.

21 Williams T: The iridoviruses. Adv Virus Res 1996;46:345-412.

22 Jakob NJ, Müller K, Bahr U, Darai G: Analysis of the first complete DNA sequence of an invertebrate iridovirus: coding strategy of the genome of Chilo iridescent virus. Virology 2001;286:182-196.

23 Federici BA: Enveloped double-stranded DNA insect virus with novel structure and cytopathology. Proc Natl Acad Sci USA 1983; 80:7664-7668.

24 Federici BA, Vlak JM, Hamm JJ: Comparative study of virion structure, protein composition and genomic DNA of three ascovirus isolates. J Gen Virol 1990;71:1661-1668.
LC, Kay-Jackson PC, Chapman D, Liverani E, Nix R, Silk R, Zhang F: African swine fever virus proteins involved in evading host defence systems. Vet Immunol Immunopathol 2004;100:117-134.

26 de Villiers EP, Gallardo C, Arias M, da Silva M, Upton C, Martin R, Bishop RP: Phylogenomic analysis of 11 complete African swine fever virus genome sequences. Virology 2010;400:128-136.

27 Wilson WH, Van Etten JL, Allen MJ: The Phycodnaviridae: the story of how tiny giants rule the world. Curr Top Microbiol Immunol 2009;328:1-42.

28 Van Etten JL, Lane LC, Dunigan DD: DNA viruses: the really big ones giruses). Annu Rev Microbiol 2010;64:83-99.

29 Van Etten JL: Unusual life style of giant chlorella viruses. Annu Rev Genet 2003;37:153195.

- 30 Wilson WH, Schroeder DC, Allen MJ, Holden MT, Parkhill J, Barrell BG, Churcher C, Hamlin N, Mungall K, Norbertczak H, et al: Complete genome sequence and lytic phase transcription profile of a Coccolithovirus. Science 2005;309:1090-1092.

31 Fuhrman JA: Marine viruses and their biogeochemical and ecological effects. Nature 1999;399:541-548.

-32 Raoult D, La Scola B, Birtles R: The discovery and characterization of Mimivirus, the largest known virus and putative pneumonia agent. Clin Infect Dis 2007;45:95-102.

33 Lwoff A: The concept of virus. J Gen Microbiol 1957;17:239-253.

- 34 Boyer M, Madoui M-A, Gimenez G, La Scola B, Raoult D: Phylogenetic and phyletic studies of informational genes in genomes highlight existence of a 4th domain of life including giant viruses. PloS One 2010; 5:e15530.

35 Fischer MG, Suttle CA: A virophage at the origin of large DNA transposons. Science 2011;332:231-234.

36 Woese CR, Kandler O, Wheelis ML: Towards a natural system of organisms: proposal for the domains Archaea, Bacteria, and Eucarya. Proc Natl Acad Sci USA 1990; 87:4576-4579.

37 Koonin EV, Senkevich TG, Dolja VV: The ancient virus world and evolution of cells. Biol Direct 2006;1:29.

38 Ivanovski D: Über die Mosaikkrankheit der Tabakspflanze. St Petersb Acad Imp Sci Bull 1892;35:67-70.

39 Beijerinck MW: Über ein Contagium vivum fluidum als Ursache der Fleckenkrankheit der Tabaksblätter. Verhandelingen der Koninklyke akademie van Wettenschappen te Amsterdam; in Johnson J (ed): Phytopathological Classics No 7. St Paul, American Phytopathological Society, 1942, pp $33-$ 52.

40 Lustig A, Levine AJ: One hundred years of virology. J Virol 1992;66:4629-4631.
41 Roening G, Holowczak JA: Evidence for the presence of RNA in the purified virions of vaccinia virus. J Virol 1974;14:704-708.

42 Filée J, Chandler M: Gene exchange and the origin of giant viruses. Intervirology 2010; 53:354-361.

43 Koonin EV, Wolf YI, Nagasaki K, Dolja VV: The Big Bang of picorna-like virus evolution antedates the radiation of eukaryotic supergroups. Nat Rev Microbiol 2008;6:925-939.

44 Raoult D: The post-Darwinist rhizome of life. Lancet 2010;375:104-105.

45 Williams TA, Embley TM, Heinz E: Informational gene phylogenies do not support a fourth domain of life for nucleocytoplasmic large DNA viruses. PLoS One 2011;6:e21080.

-46 Wu D, Wu M, Halpern A, Rusch DB, Yooseph S, Frazier M, Venter JC, Eisen JA: Stalking the fourth domain in metagenomic data: searching for, discovering, and interpreting novel, deep branches in marker gene phylogenetic trees. PLoS One 2011;6:e18011.

- 47 Novoa RR, Calderita G, Arranz R, Fontana J, Granzow H, Risco C: Virus factories: associations of cell organelles for viral replication and morphogenesis. Biol Cell 2005;97:147172 .

48 Suzan-Monti M, La Scola B, Barrassi L, Espinosa L, Raoult D: Ultrastructural characterization of the giant volcano-like virus factory of Acanthamoeba polyphaga Mimivirus. PLoS One 2007;2:e328.

-49 Suzan-Monti M, La Scola B, Raoult D: Genomic and evolutionary aspects of Mimivirus. Virus Res 2006;117:145-155.

50 Suhre K: Gene and genome duplication in Acanthamoeba polyphaga Mimivirus. J Virol 2005;79:14095-14101.

51 Filée J: Lateral gene transfer, lineage-specific gene expansion and the evolution of nucleocytoplasmic large DNA viruses. J Invertebr Pathol 2009;101:169-171.

52 Moreira D, Brochier-Armanet C: Giant viruses, giant chimeras: the multiple evolutionary histories of Mimivirus genes. BMC Evol Biol 2008;8:12.

53 Colson P, Raoult D: Gene repertoire of amoeba-associated giant viruses. Intervirology 2010;53:330-343

54 Shackelton LA, Holmes EC: The evolution of large DNA viruses: combining genomic information of viruses and their hosts. Trends Microbiol 2004;12:458-465.

55 McLysaght A, Baldi PF, Gaut BS: Extensive gene gain associated with adaptive evolution of poxviruses. Proc Natl Acad Sci USA 2003; 100:15655-15660.

56 Evans DH, Stuart D, McFadden G: High levels of genetic recombination among cotransfected plasmid DNAs in poxvirus-infected mammalian cells. J Virol 1988;62: 367-375.

57 Pickup DJ, Ink BS, Parsons BL, Hu W, Joklik WK: Spontaneous deletions and duplications of sequences in the genome of cowpox virus. Proc Natl Acad Sci USA 1984;81:68176821. 
58 Raoult D, Boyer M: Amoebae as genitors and reservoirs of giant viruses. Intervirology 2010;53:321-329.

59 Boyer M, Azza S, Barrassi L, Klose T, Campocasso A, Pagnier I, Fournous G, Borg A, Robert C, Zhang X, et al: Mimivirus shows dramatic genome reduction after intraamoebal culture. Proc Natl Acad Sci USA 2011;108:10296-10301.

60 Boyer M, Gimenez G, Suzan-Monti M, Raoult D: Classification and determination of possible origins of ORFans through analysis of nucleocytoplasmic large DNA viruses. Intervirology 2010;53:310-320.

-61 Desnues C, Boyer M, Raoult D: Sputnik, a virophage infecting the viral domain of life. Adv Vir Res 2012;82:63-89.

62 Yau S, Lauro FM, Demaere MZ, Brown MV, Thomas T, Raftery MJ, Andrews-Pfannkoch C, Lewis M, Hoffman JM, Gibson JA, et al: Virophage control of antarctic algal host-virus dynamics. Proc Natl Acad Sci USA 2011; 108:6163-6168.

63 Edwards RA, Rohwer F: Viral metagenomics. Nat Rev Microbiol 2005;3:504-510.
64 Angly FE, Willner D, Prieto-Davó A, Edwards RA, Schmieder R, Vega-Thurber R, Antonopoulos DA, Barott K, Cottrell MT, Desnues C, et al: The GAAS metagenomic tool and its estimations of viral and microbial average genome size in four major biomes. PLoS Comput Biol 2009; 5:e1000593.

65 Thurber RV, Haynes M, Breitbart M, Wegley L, Rohwer F: Laboratory procedures to generate viral metagenomes. Nat Protoc 2009; 4 470-483.

66 Ghedin E, Claverie JM: Mimivirus relatives in the Sargasso Sea. Virol J 2005;2:62.

67 Rusch DB, Halpern AL, Sutton G, Heidelberg KB, Williamson S, Yooseph S, Wu D, Eisen JA, Hoffman JM, Remington K, et al: The Sorcerer II Global Ocean Sampling expedition: northwest Atlantic through eastern tropical Pacific. PLoS Biol 2007;5:e77.

68 Monier A, Larsen JB, Sandaa RA, Bratbak G, Claverie JM, Ogata H: Marine mimivirus relatives are probably large algal viruses. Virol J 2008;5:12.
9 Ogata H, Toyoda K, Tomaru Y, Nakayama N, Shirai Y, Claverie JM, Nagasaki K: Remarkable sequence similarity between the dinoflagellate-infecting marine girus and the terrestrial pathogen African swine fever virus. Virol J 2009;6:178.

70 Loh J, Zhao G, Presti RM, Holtz LR, Finkbeiner SR, Droit L, Villasana Z, Todd C, Pipas JM, Calgua B, et al: Detection of novel sequences related to African swine fever virus in human serum and sewage. J Virol 2009;83:13019-13025.

71 Kristensen DM, Mushegian AR, Dolja VV, Koonin EV: New dimensions of the virus world discovered through metagenomics. Trends Microbiol 2010;18:11-19.

72 Condit RC: Principles of virology; in Knipe DM, Howley PM (eds): Fields Virology, ed 5, Philadelphia, Lippincott Williams \& Wilkins, 2007.

73 Moss B: Poxviridae: the viruses and their replication; in Fields BN, Knipe DM, Howley PM (eds): Fields Virology, ed 3. Philadelphia, Lippincott-Raven, 1996, pp 2637-2671. 